\title{
Tolerance to bovine clinical mastitis: Total, direct, and indirect milk losses
}

\author{
J. Detilleux ${ }^{1}$ \\ FARAH, Productions animales durables, Faculty of Veterinary Medicine, University of Liege, Quartier Vallée 2, 6 Avenue de Cureghem, \\ 4000 Liège, Belgium
}

\begin{abstract}
The objectives of this paper were to estimate direct and indirect milk losses associated with mastitis. Indirect losses, linked to indirect tolerance, are mediated by the increase in milk somatic cell count (SCC) in response to bacterial infection. Direct losses, linked to weak direct tolerance, are not mediated by the increase in SCC. So far, studies have evaluated milk loss associated with clinical mastitis without considering both components, which may lead to biased estimates of their sum; that is, the total loss in milk. A total of 43,903 test-day records on milk and SCC from 3,716 cows and 5,858 lactations were analyzed with mediation mixed models and health trajectories to estimate the amount of direct, indirect, and total milk losses after adjustment for known and potentially unmeasured (sensitivity analyses) confounding factors. Estimates were formalized under the counterfactual causal theory of causation. In this study, milk losses were mostly mediated by an increase in SCC. They were highest in the first month of lactation, when SCC were highest. Milk losses were estimated at $0.5,0.8$, and $1.1 \mathrm{~kg} / \mathrm{d}$ in first, second, and third and greater parity, respectively. Two phases described how changes in milk were associated with changes in SCC: on average, one occurred before and one after the day preceding the clinical diagnosis. In both phases, changes in milk were estimated at $1 \mathrm{mg} / \mathrm{d}$ per $10^{3}$ cells $/ \mathrm{mL}$. After adjusting for known confounders, cow effect accounted for 20.7 and $64.2 \%$ of the variation in milk in the first and second phases, respectively. This suggests that deviations from the resilient path were highest during the second phase of inflammation and that selection for cows more tolerant to mastitis is feasible. As discussed herein, epigenetic regulation of macrophage polarization may contribute to the variation in milk observed in the second phase.
\end{abstract}

Received October 10, 2017.

Accepted November 28, 2017.

${ }^{1}$ Corresponding author: jdetilleux@ulg.ac.be
Key words: mastitis, health trajectory, mediation, tolerance, counterfactual

\section{INTRODUCTION}

Milk production decreases in cows with mastitis and the amount of milk lost is influenced by several factors including the level of "tolerance" of infected cows. Tolerance (e.g., Råberg et al., 2007) is the ability to reduce the negative consequences of infection by reducing the damage caused by pathogens (direct tolerance) or by the host response triggered by the infection (indirect tolerance). The distinction is important because only mechanisms of indirect tolerance are linked to those of resistance. The spread of an infectious disease will be limited without loss in performance if cows are resistant and indirectly tolerant. The distinction is also important because of the restrictions on therapeutics of mastitis. Usually, these include antimicrobials to kill bacteria (to be used to treat cows not directly tolerant) and anti-inflammatory drugs to reduce damage due to immune response (to be used to treat cows indirectly not tolerant).

In bovine mastitis, indirect tolerance mechanisms oppose effects of immune cells, including neutrophils that migrate from the blood into the infected gland. Routinely, this migration is evaluated by milk SCC. Then, milk loss mediated by the increase in SCC can be considered as a consequence of limited indirect tolerance (called "indirect loss" hereafter). Conversely, milk loss not mediated by the increase in SCC can be regarded as a consequence of limited direct tolerance (called "direct loss"). The sum of both represents the "total loss."

With a few exceptions (Detilleux et al., 2015), it is difficult to find separate estimates of milk losses in the literature. For example, Hagnestam-Nielsen et al. (2009) estimated losses by comparing test-day milk yields (TDM) of cows with and without mastitis after adjusting for confounding factors known to affect milk production but without considering concomitant changes in SCC. These are estimates of the total loss. In other studies, researchers estimated milk losses by 
regressing measures of SCC on TDM, also adjusting for various control variables (e.g., Koldeweij et al., 1999; Dürr et al., 2008) but without knowing the mastitis status of the cows. These are estimates of the indirect loss.

Mediation analyses can be used to obtain separate estimates of milk losses. In these analyses, a mediating variable (e.g., SCC) conveys the influence of an independent variable (e.g., presence vs. absence of clinical mastitis) on a dependent variable (e.g., TDM). Then, under the counterfactual framework (e.g., Vanderweele and Vansteelandt, 2009; Richiardi et al., 2013), the direct effect would be measured by the expected difference in TDM in the presence versus absence of mastitis when SCC remain unchanged. The indirect effect is measured by the expected difference in TDM when SCC are measured in the presence and absence of mastitis.

It has also been argued that estimates of tolerance may be different according to the stage of infection and that health trajectories may capture this dynamic (Schneider, 2011; Lough et al., 2015). Health trajectories are curves that link the values of indicators of health and infection at many time points over the course of the disease. This produces looping curves that can be partitioned in different sections reflecting different infection stages. They are also useful to determine whether diseased individuals recover and if the infection is cleared (resilient system).

The goals of this study were (1) to apply a mediation model on and construct heath trajectories of TDM collected during a field study on cows with and without clinical mastitis; (2) to obtain estimates of associated total, direct, and indirect milk losses; and (3) to interpret these estimates under the counterfactual framework.

\section{MATERIALS AND METHODS}

\section{Data Description}

Data came from a 3-yr survey of 30 commercial dairy farms conducted by the group "Observatory for Udder Health (OSaM)" that connects researchers, dairy associations, and breeders in collecting information on farm, animal, and clinical mastitis events in the Walloon region of Belgium (Reding et al., 2011). Herds were enrolled in the regional dairy herd recording system from which monthly TDM $(\mathrm{L} / \mathrm{d})$ and SCC $\left(\times 10^{3}\right.$ cells $\left./ \mathrm{mL}\right)$ data were obtained. Edited data included TDM and SCC collected within the first 10 mo of lactation from cows in parity 1 to 3 . When information was missing, it was imputed by linear interpolation between clos- est values. Other information included year of calving, parity, DIM, and number of days between successive events.

Clinical mastitis was diagnosed by the breeder when milk from one or more glands was abnormal in color, viscosity, or consistency, with or without accompanying signs of heat, pain, or redness. Two indicators of clinical mastitis (CM) were created: (1) if TDM and SCC were sampled on the day of diagnosis, then the first indicator (CM1) was set to 1 , and at 0 otherwise; (2) if TDM and SCC were sampled 15 d before until 70 d after the day of diagnosis, then the second indicator (CM2) was set to 1 , and at 0 otherwise. For records with $\mathrm{CM} 2=1$, individual trajectories were constructed by plotting individual measurements of TDM against SCC in 2-dimensional space at different times with respect to the day of diagnosis. The range was chosen in reference to the study by Gröhn et al. (2004), who observed a decline in milk yield in the period from $15 \mathrm{~d}$ before until $70 \mathrm{~d}$ after diagnosis of mastitis.

\section{Estimation of Milk Losses}

Mediation Models. Two multiple regression equations (model [1]) were used to estimate the effects of clinical mastitis on TDM: one to estimate the effect of CM1 (or CM2) on SCC and the other to estimate the effects of CM1 (or CM2) and SCC on TDM:

$$
\begin{gathered}
\mathrm{E}\left(\mathrm{Y}^{\mathrm{i}, \mathrm{t}}\right)=\nu+\beta_{1} \mathrm{~A}^{\mathrm{i}, \mathrm{t}}+\beta_{2} \mathrm{M}^{\mathrm{i}, \mathrm{t}}+\beta_{3} \mathrm{C}^{\mathrm{i}, \mathrm{t}}+\beta_{4} \mathrm{AM}^{\mathrm{i}, \mathrm{t}} \\
+\beta_{5} \mathrm{CM}^{\mathrm{i}, \mathrm{t}}+\beta_{6} \mathrm{AC}^{\mathrm{i}, \mathrm{t}}+\beta_{7} \mathrm{AMC}^{\mathrm{i}, \mathrm{t}} \\
\mathrm{E}\left(\mathrm{M}^{\mathrm{i}, \mathrm{t}}\right)=\exp \left(\mu+\delta_{1} \mathrm{~A}^{\mathrm{i}, \mathrm{t}}+\delta_{3} \mathrm{C}^{\mathrm{i}, \mathrm{t}}+\delta_{6} \mathrm{AC}^{\mathrm{i}, \mathrm{t}}\right)
\end{gathered}
$$

where $\mathrm{Y}^{\mathrm{i}, \mathrm{t}}\left(\mathrm{M}^{\mathrm{i}, \mathrm{t}}\right)$ is the TDM (SCC) record of the ith cow at the th day in lactation $(\mathrm{t}=1,2, \ldots 300), v$ and $\mu$ are the overall means; $A^{i, t}$ is the indicator variable for mastitis (either CM1 or CM2); $\mathrm{C}^{\mathrm{i}, \mathrm{t}}$ represents the indicator variables for the known confounders in the association between TDM, SCC, and mastitis; $\beta_{\mathrm{j}}\left(\delta_{\mathrm{k}}\right)$ is the regression coefficient of $\mathrm{Y}^{\mathrm{i}, \mathrm{t}}\left(\mathrm{M}^{\mathrm{i}, \mathrm{t}}\right)$ on an explanatory variable for $\mathrm{j}=1,2, \ldots, 7$ and $\mathrm{k}=1,3,6$. For example, the regression coefficient $\beta_{1}$ represents the change in TDM due to the presence of mastitis, keeping all other variables in the model held constant. The confounders are herd-year-season $(1,2, \ldots, 372)$, parity $(1,2,3)$, and month in lactation $(1,2, \ldots, 10)$. Cow effect and residual were considered random and distributed normally and independently with null mean and variances that account for the repeated nature of the data (compound symmetry). The Genmod and Mixed procedures of SAS (version 9.3; SAS Institute Inc., Cary, NC) were 
used to fit SCC (overdispersed Poisson) and TDM (normal) distributions, respectively, and significance levels were set at $5 \%$.

Counterfactual Definition. The counterfactual definitions of total, direct, and indirect losses are as follows. The total loss is the difference between means of TDM in the presence versus the absence of clinical signs of mastitis. The direct loss is the mean difference in TDM that is independent of the effect of mastitis on SCC and the indirect loss is the mean difference in TDM that results only from the influence of mastitis on SCC. In mathematical terms, these losses are given in model [2]:

$$
\begin{aligned}
& {\left[\mathrm{Y}_{1, \mathrm{M}(1)}^{\mathrm{i}, \mathrm{t}}-\mathrm{Y}_{0, \mathrm{M}(0)}^{\mathrm{i}, \mathrm{t}}\right]} \\
& =\frac{1}{2}\left\{\begin{array}{l}
{\left[\mathrm{Y}_{1, \mathrm{M}(1)}^{\mathrm{i}, \mathrm{t}}-\mathrm{Y}_{0, \mathrm{M}(1)}^{\mathrm{i}, \mathrm{t}}\right]+\left[\mathrm{Y}_{1, \mathrm{M}(0)}^{\mathrm{i}, \mathrm{t}}-\mathrm{Y}_{0, \mathrm{M}(0)}^{\mathrm{i}, \mathrm{t}}\right]} \\
+\left[\mathrm{Y}_{0, \mathrm{M}(1)}^{\mathrm{i}, \mathrm{t}(1)}-\mathrm{Y}_{0, \mathrm{M}(0)}^{\mathrm{i}, \mathrm{t}}\right]+\left[\mathrm{Y}_{1, \mathrm{M}(1)}^{\mathrm{i}, \mathrm{t}}-\mathrm{Y}_{1, \mathrm{M}(0)}^{\mathrm{i}, \mathrm{t}}\right]
\end{array}\right\},
\end{aligned}
$$

in which $\mathrm{Y}_{1, \mathrm{M}(1)}^{\mathrm{i}, \mathrm{t}}$ represents TDM that would be observed during a mastitis episode if SCC were set at the value observed during the mastitis episode; $\mathrm{Y}_{0, \mathrm{M}(0)}^{\mathrm{i}, \mathrm{t}}$ represents TDM that would be observed when there are no clinical signs of mastitis for SCC set at the value it would have when there are no clinical signs of mastitis; $\mathrm{Y}_{0, \mathrm{M}(1)}^{\mathrm{i}, \mathrm{t}}$ represents milk yield that would be observed in the absence of clinical signs of mastitis for SCC set at the value it would have in the presence of clinical signs; and $\mathrm{Y}_{1, \mathrm{M}(0)}^{\mathrm{i}, \mathrm{t}}$ represents milk yield that would be observed in the presence of clinical signs of mastitis for SCC set at the value it would have in the absence of clinical signs (Vanderweele and Vansteelandt, 2009). At the population level, the expected value of the left-hand-side term of the equation represents the total loss. Half the expected value of the sum of the first 2 right-hand-side terms is the direct effect. Half the expected value of the sum of the last 2 right-hand-side terms is the indirect effect. In the Appendix, total, direct, and indirect losses are expressed in terms of the statistical models [3], [4], and [5], respectively.

Sensitivity Analyses. Known confounders that affect both SCC and TDM were considered but it is still possible that unknown confounders were unmeasured and biased the results. To evaluate that risk, a sensitivity analysis was carried out by adding simulated confounders in the equations for $\mathrm{E}\left(\mathrm{Y}^{\mathrm{i}, \mathrm{t}}\right)$ and $\mathrm{E}\left(\mathrm{M}^{\mathrm{i}, \mathrm{t}}\right)$ and evaluating the effect of this addition on the estimates of losses. Then, following Carnegie et al. (2016), equations in model [6] are

$$
\begin{gathered}
\mathrm{E}\left(\mathrm{Y}^{\mathrm{i}, \mathrm{t}}\right)=\nu+\beta_{1} \mathrm{~A}^{\mathrm{i}, \mathrm{t}}+\beta_{2} \mathrm{M}^{\mathrm{i}, \mathrm{t}}+\beta_{3} \mathrm{C}^{\mathrm{i}, \mathrm{t}}+\beta_{4} \mathrm{AM}^{\mathrm{i}, \mathrm{t}} \\
+\beta_{5} \mathrm{CM}^{\mathrm{i}, \mathrm{t}}+\beta_{6} \mathrm{AC}^{\mathrm{i}, \mathrm{t}}+\beta_{7} \mathrm{AMC}^{\mathrm{i}, \mathrm{t}}+\lambda_{\mathrm{y}} \mathrm{U}_{\mathrm{y}} \\
\text { and } \mathrm{E}\left(\mathrm{M}^{\mathrm{i}, \mathrm{t}}\right)=\exp \left(\mu+\delta_{1} \mathrm{~A}^{\mathrm{i}, \mathrm{t}}+\delta_{3} \mathrm{C}^{\mathrm{i}, \mathrm{t}}\right. \\
\left.+\delta_{6} \mathrm{AC}^{\mathrm{i}, \mathrm{t}}+\lambda_{\mathrm{m}} \mathrm{U}_{\mathrm{m}}\right),
\end{gathered}
$$

where $\mathrm{U}_{\mathrm{y}}$ and $\mathrm{U}_{\mathrm{m}}$ are the unmeasured confounders, and regression parameters $\lambda_{\mathrm{y}}$ and $\lambda_{\mathrm{m}}$ act as sensitivity parameters. Both $U_{y}$ and $U_{m}$ were assumed to be a linear combination of all potential unmeasured confounders. Hence, they are approximately normally distributed for a sufficient number of confounders. A total of 100 simulated values for $U_{y}$ and $U_{m}$ were drawn from their distributions and for different combinations of values for the sensitivity parameters (i.e., $\lambda_{\mathrm{y}}=-10$ to +10 and $\lambda_{\mathrm{m}}=-10$ to +10$)$. With these values, $\mathrm{U}_{\mathrm{y}}$ and $\mathrm{U}_{\mathrm{m}}$ were assumed to have a large (or a small) positive (or negative) effect on TDM and SCC. For each value of $U_{y}$ and $\mathrm{U}_{\mathrm{m}}$, new estimates of the regression coefficients $\beta_{1}, \beta_{2}$, and $\delta_{1}$ were computed. These estimates and their corresponding standard error estimates were used to compute mean and variances over all combinations: $v=$ $1 / \mathrm{K} \Sigma v_{\mathrm{k}}$ and $\sigma^{2}=\mathrm{W}+(1+1 / \mathrm{K}) \mathrm{B}$, where $\mathrm{W}=1 / \mathrm{K} \Sigma \sigma_{\mathrm{k}}^{2}$ and $\mathrm{B}=[1 /(\mathrm{K}-1)] \Sigma\left(v_{\mathrm{k}}-v\right)^{2}$, where $v_{\mathrm{k}}$ is the kth estimate of $\beta_{1}, \beta_{2}$, or $\delta_{1}$ with $\mathrm{k}=1,2, \ldots, \mathrm{K}$ (Carnegie et al., 2016).

Analysis of Trajectories. Trajectories were analyzed in 2 steps. First, individual SCC were analyzed with a segmented Poisson regression model to obtain the time at which dynamics of SCC changed (model $[7])$ :

$$
\begin{gathered}
\log \mathrm{E}\left(\mathrm{M}^{\mathrm{i}, \mathrm{t}}\right)=\theta+\delta_{1} \mathrm{D}^{\mathrm{i}, \mathrm{t}}+\Sigma_{\mathrm{k}} \delta_{\mathrm{k}}\left(\mathrm{D}^{\mathrm{i}, \mathrm{t}}-\mathrm{D}_{\mathrm{k}-1}\right) \mathrm{I}_{\mathrm{k}} \\
\text { for } \mathrm{k}=2, \ldots, \mathrm{K},
\end{gathered}
$$

where $\mathrm{M}^{\mathrm{i}, \mathrm{t}}$ is the SCC record of the ith cow at the tth day in lactation, $\mathrm{D}^{\mathrm{i}, \mathrm{t}}$ is the day with respect to diagnosis, $\theta$ is the intercept, $\delta_{1}$ is the slope of the first left segment, $\delta_{k}$ is the kth "difference in slopes," $D_{k}$ is the kth day at which the trend in SCC is changing, $I_{k}$ is the kth indicator variable taking the value of 1 if $\mathrm{D}^{\mathrm{i}, \mathrm{t}}>\mathrm{D}_{\mathrm{k}}$ and 0 otherwise, $\mathrm{K}$ is the number of breakpoints such that $\mathrm{D}_{1} \leq \mathrm{D}_{2} \leq \mathrm{D}_{3} \leq \ldots \mathrm{D}_{\mathrm{K}}$. The number of breakpoints $\mathrm{K}$ was chosen after visual inspection of the mean of individual trajectories and the procedure NLIN was used to estimate the parameters. Next, TDM were analyzed separately before and after $D_{k}$ to determine whether losses per unit of SCC were different across infection stages. The same model (model [8]) was applied before and after each $\mathrm{D}_{\mathrm{k}}$ on TDM measurements. This model is a subset of model [1]: 
Table 1. Overall means (SE in parentheses) of test-day SCC and milk yields, and percentages of test-day records with signs of clinical mastitis (cases) at the time of sampling

\begin{tabular}{|c|c|c|c|c|}
\hline Variable & Category & $\begin{array}{c}\mathrm{SCC} \\
\left(\times 10^{3} \text { cells } / \mathrm{mL}\right)\end{array}$ & $\begin{array}{l}\text { Milk yield } \\
\text { (L/d) }\end{array}$ & $\begin{array}{l}\text { Percentage } \\
\text { of cases }\end{array}$ \\
\hline \multirow[t]{3}{*}{ Parity } & First & $187.37(4.75)$ & $24.00(0.05)$ & 0.71 \\
\hline & Second & $266.79(6.70)$ & $27.62(0.07)$ & 1.07 \\
\hline & Third & $433.49(7.35)$ & $29.25(0.07)$ & 1.53 \\
\hline \multirow[t]{4}{*}{ Month of sampling } & January-March & $309.88(7.57)$ & $28.40(0.07)$ & 1.29 \\
\hline & April-June & $309.75(7.19)$ & $27.39(0.07)$ & 1.13 \\
\hline & July-September & $315.52(8.49)$ & $25.36(0.09)$ & 1.78 \\
\hline & October-December & $323.73(7.78)$ & $26.72(0.08)$ & 2.32 \\
\hline \multirow[t]{3}{*}{ Year of survey } & First & $296.28(6.96)$ & $26.57(0.07)$ & 0.78 \\
\hline & Second & $318.39(7.02)$ & $26.69(0.07)$ & 0.83 \\
\hline & Third & $321.28(6.14)$ & $27.88(0.06)$ & 2.96 \\
\hline \multirow{10}{*}{ Month in milk } & 1 & $374.25(22.04)$ & $28.73(0.17)$ & 0.76 \\
\hline & 2 & $288.71(11.80)$ & $31.59(0.12)$ & 1.11 \\
\hline & 3 & $281.79(11.58)$ & $31.67(0.12)$ & 1.71 \\
\hline & 4 & $309.65(12.39)$ & $29.98(0.11)$ & 1.69 \\
\hline & 5 & 303.39 (11.44) & $28.44(0.10)$ & 1.09 \\
\hline & 6 & 339.68 (13.03) & $26.84(0.10)$ & 1.22 \\
\hline & 7 & $298.52(10.32)$ & $25.44(0.10)$ & 0.76 \\
\hline & 8 & $306.40(11.93)$ & $23.96(0.10)$ & 0.95 \\
\hline & 9 & $319.28(11.35)$ & $22.31(0.10)$ & 0.67 \\
\hline & 10 & $312.73(10.54)$ & $20.40(0.10)$ & 1.13 \\
\hline
\end{tabular}

$$
\mathrm{E}\left(\mathrm{Y}^{\mathrm{i}, \mathrm{t}}\right)=\nu+\beta_{2} \mathrm{M}^{\mathrm{i}, \mathrm{t}}+\beta_{3} \mathrm{C}^{\mathrm{i}, \mathrm{t}}+\beta_{5} \mathrm{CM}^{\mathrm{i}, \mathrm{t}}
$$

where symbols and assumptions are the same as in model [1].

\section{RESULTS}

\section{Descriptive Statistics}

Data included 43,903 test-day records from 3,716 cows and 5,858 lactations. The percentage of imputed data was $1.61 \%$. As parity number and year of survey increased, means of SCC and TDM and percentages of clinical cases increased (Table 1). Percentages of mastitis and SCC means were highest for samples taken between July and December, and TDM means were lowest during the same period. Mastitis cases occurred throughout the lactation, with the highest frequency in the third month in lactation (Table 1). Means for $\mathrm{TDM}$ and $\mathrm{SCC}$ in cows with $\mathrm{CM} 1=1$ and $\mathrm{CM} 1=0$ are given in Figure 1. Overall, SCC means were higher (TDM means were lower) in samples from cows with than without mastitis.

\section{Milk Losses}

Results of the regression analyses showed that SCC and all confounders in the models significantly influenced TDM (Tables 2 and 3). Inversely, CM1, CM2, and all interaction terms (with the exception of the interaction of SCC with parity number) had no sig- nificant effect on TDM. Presence of mastitis and all confounders in the model significantly influenced SCC (no significant interaction effects between these factors), which suggests that SCC mediate the association between TDM and mastitis and that confounders moderate this association. Cow effects accounted for $40 \%$ of the total variation.

Equations for total, direct, and indirect milk losses (Models [3], [4], and [5]) simplify because interaction terms (with the exception of the interaction of SCC with parity number) were not significant. Thus, total, direct, and indirect milk losses were estimated as

$$
\begin{aligned}
& \hat{\mathrm{E}}\left[\mathrm{Y}_{1, \mathrm{M}(1)}^{\mathrm{i}, \mathrm{t}}-\mathrm{Y}_{0, \mathrm{M}(0)}^{\mathrm{i}, \mathrm{t}}\right] \\
& =\mathrm{b}_{1}+\left(\mathrm{b}_{2}+\mathrm{b}_{5} \mathrm{C}^{\mathrm{i}, \mathrm{t}}\right)\left\{\exp \left(\mathrm{m}+\mathrm{d}_{1}+\mathrm{d}_{3} \mathrm{C}^{\mathrm{i}, \mathrm{t}}\right)-\exp \left(\mathrm{m}+\mathrm{d}_{3} \mathrm{C}^{\mathrm{i}, \mathrm{t}}\right)\right\} \\
& =\mathrm{b}_{1}+\left(\mathrm{b}_{2}+\mathrm{b}_{5} \mathrm{C}^{\mathrm{i}, \mathrm{t}}\right)\left\{\exp \left(\mathrm{m}+\mathrm{d}_{3} \mathrm{C}^{\mathrm{i}, \mathrm{t}}\right)\left[\exp \left(\mathrm{d}_{1}\right)-1\right]\right\}, \\
& \frac{1}{2} \hat{\mathrm{E}}\left\{\left[\mathrm{Y}_{1, \mathrm{M}(1)}^{\mathrm{i}, \mathrm{t}}-\mathrm{Y}_{0, \mathrm{M}(1)}^{\mathrm{i}, \mathrm{t}}\right]+\left[\mathrm{Y}_{1, \mathrm{M}(0)}^{\mathrm{i}, \mathrm{t}}-\mathrm{Y}_{0, \mathrm{M}(0)}^{\mathrm{i}, \mathrm{t}}\right]\right\}=\mathrm{b}_{1}, \\
& \frac{1}{2} \hat{\mathrm{E}}\left\{\left[\mathrm{Y}_{0, \mathrm{M}(1)}^{\mathrm{i}, \mathrm{t}}-\mathrm{Y}_{0, \mathrm{M}(0)}^{\mathrm{i}, \mathrm{t}}\right]+\left[\mathrm{Y}_{1, \mathrm{M}(1)}^{\mathrm{i}, \mathrm{t}}-\mathrm{Y}_{1, \mathrm{M}(0)}^{\mathrm{i}, \mathrm{t}}\right]\right\} \\
& =\left(\mathrm{b}_{2}+\mathrm{b}_{5} \mathrm{C}^{\mathrm{i}, \mathrm{t}}\right)\left\{\exp \left(\mathrm{m}+\mathrm{d}_{3} \mathrm{C}^{\mathrm{i}, \mathrm{t}}\right)\left[\exp \left(\mathrm{d}_{1}\right)-1\right]\right\},
\end{aligned}
$$

for cows in the same herd, season, parity, year, and month in milk [i.e., $\mathrm{C}_{(1)}{ }^{\mathrm{i}, \mathrm{t}}=\mathrm{C}_{(0)}^{\mathrm{i}, \mathrm{t}}=\mathrm{C}^{\mathrm{i}, \mathrm{t}}$ ]. In the equations, $m$ and $b_{j}\left(d_{k}\right)$ are the estimates of the intercept $\mu$ and the regression coefficients $\beta_{\mathrm{j}}\left(\delta_{\mathrm{k}}\right)$, respectively. For both indicators (CM1 and CM2), total and indirect losses were significantly different from null. They were 

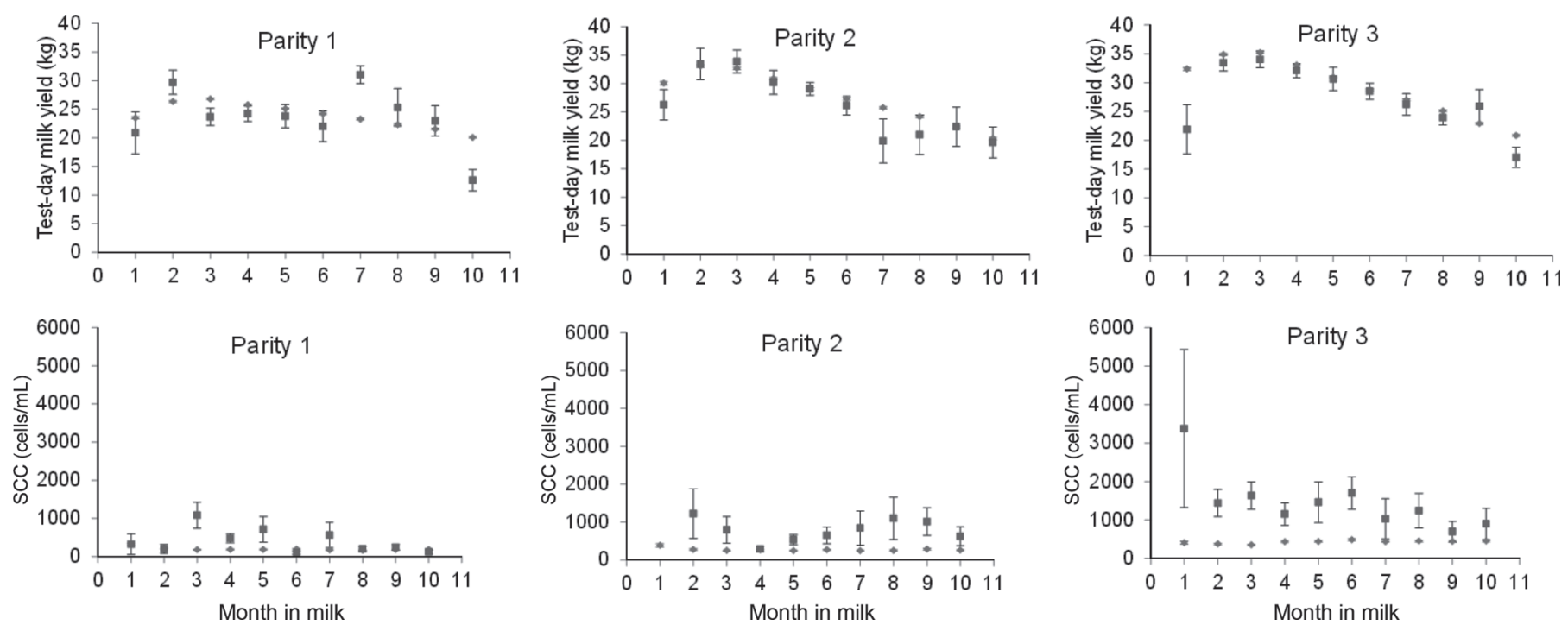

Figure 1. Observed means of test-day milk yields and SCC per month in milk from cows with at the time of sampling. Error bars represent SE.

highest in the first month in lactation (when SCC were highest) and in the third and greater parity, as shown for the total loss in Figure 2. By definition, estimates of total and indirect losses depend on the mean SCC differences in samples taken from cows with or without signs of mastitis inversely to estimates of direct losses. Estimates of direct losses were very low (i.e., $0.03 \mathrm{~L} / \mathrm{d}$ for CM1 and $00.26 \mathrm{~L} / \mathrm{d}$ for CM2).

Table 2. Regression coefficients (SE in parentheses) relating explanatory variables to test-day SCC (overdispersed Poisson model) and test-day milk yields (Gaussian linear model) ${ }^{1}$

\begin{tabular}{|c|c|c|c|}
\hline Explanatory variable & Category & $\begin{array}{c}\mathrm{SCC} \\
\left(\times 10^{3} \text { cells } / \mathrm{mL}\right)\end{array}$ & $\begin{array}{l}\text { Milk yield } \\
\text { (L/d) }\end{array}$ \\
\hline Intercept & & $6.35(0.16)$ & $26.39(0.45)$ \\
\hline $\mathrm{SCC}\left(\times 10^{3}\right.$ cells $\left./ \mathrm{mL}\right)$ & & $\mathrm{NA}^{2}$ & $-1.06(0.04) \times 10^{-3}$ \\
\hline \multirow[t]{2}{*}{ Indicator variable } & Clinical signs & $1.02(0.09)$ & $-0.03(0.25)$ \\
\hline & No clinical signs & 0 (referent) & 0 (referent) \\
\hline \multirow[t]{3}{*}{ Parity } & 1 & $-0.87(0.04)$ & $-5.76(0.11)$ \\
\hline & 2 & $-0.54(0.04)$ & $-1.93(0.08)$ \\
\hline & 3 & 0 (referent) & 0 (referent) \\
\hline \multirow[t]{10}{*}{ Month in milk } & 1 & $0.19(0.07)$ & $8.50(0.13)$ \\
\hline & 2 & $-0.09(0.05)$ & $11.24(0.10)$ \\
\hline & 3 & $-0.09(0.05)$ & $11.27(0.10)$ \\
\hline & 4 & $-0.04(0.05)$ & $9.46(0.10)$ \\
\hline & 5 & $-0.05(0.05)$ & $7.73(0.10)$ \\
\hline & 6 & $0.04(0.05)$ & $6.24(0.10$ \\
\hline & 7 & $-0.07(0.05)$ & $4.73(0.10)$ \\
\hline & 8 & $-0.04(0.05)$ & $3.37(0.10)$ \\
\hline & 9 & $0.02(0.04)$ & $1.82(0.10)$ \\
\hline & 10 & 0 (referent) & 0 (referent) \\
\hline \multirow{3}{*}{ Year of survey } & First & $0.03(0.07)$ & $-0.73(0.12)$ \\
\hline & Second & $0.23(0.06)$ & $-0.87(0.11)$ \\
\hline & Third & 0 (referent) & 0 (referent) \\
\hline \multirow[t]{4}{*}{ Month of sampling } & January-March & $0.15(0.06)$ & $1.28(0.11)$ \\
\hline & April-June & $0.09(0.06)$ & $2.26(0.11)$ \\
\hline & July-September & $0.15(0.06)$ & $0.62(0.11)$ \\
\hline & October-December & 0 (referent) & 0 (referent) \\
\hline \multirow{3}{*}{ Interaction $\mathrm{SCC} \times$ parity } & 1 & NA & $0.28(0.03) \times 10^{-3}$ \\
\hline & 2 & NA & $0.01(0.00) \times 10^{-3}$ \\
\hline & 3 and over & NA & 0 (referent) \\
\hline
\end{tabular}

${ }^{1}$ The indicator variable is for the presence or not of clinical signs on the test day.

${ }^{2}$ Not applicable. 
Sensitivity analyses showed that results were not influenced by potentially unmeasured confounders for both indicators (CM1 and CM2). For CM1 as an example, means over all combinations of $\mathrm{U}_{\mathrm{y}}$ and $\mathrm{U}_{\mathrm{m}}$ were $-0.08(\mathrm{SE}=0.23) \mathrm{kg} / \mathrm{d},-0.11 \times 10^{-2}(\mathrm{SE}=0.04 \times$ $\left.10^{-3}\right) \mathrm{kg} / \mathrm{d}$ per $10^{3}$ cells $/ \mathrm{mL}$, and $+1.08(\mathrm{SE}=0.08)$ $\mathrm{kg} / \mathrm{d}$ per $10^{3}$ cells $/ \mathrm{mL}$ for $\beta_{1}, \beta_{2}$, and $\delta_{1}$, respectively. These are close to the estimates obtained in the absence of confounders: $-0.03(\mathrm{SE}=0.25),-0.11 \times 10^{-2}(\mathrm{SE}=$ $\left.0.04 \times 10^{-3}\right)$, and $+1.02(\mathrm{SE}=0.09)$ for $\beta_{1}, \beta_{2}$, and $\delta_{1}$, respectively (Table 2 ).

\section{Health Trajectories}

Means of weekly TDM and SCC for samples taken 15 d before until $70 \mathrm{~d}$ after the day of diagnosis (CM2 = 1) are given in Figure 3. Milk decreased before diagnosis and returned to initial values 6 wk after diagnosis. Concurrently, SCC increased up to the first week after diagnosis before returning to initial values. Trajectory on the mean values of SCC and TDM is shown in Figure 4. Two phases can be observed: one in which SCC increase and TDM decrease, and one in which SCC decrease and TDM increase.
Results of the segmented regression on daily changes in SCC were that the breakpoint was at $\mathrm{d}-1.01$ (SE $=2.08$ ). Before the breakpoint, TDM decreased significantly by $1.83(\mathrm{SE}=0.51) \mathrm{mg} / 10^{3}$ cells $/ \mathrm{mL}$ over the period of 2 wk. After the breakpoint, TDM decreased by $0.74(\mathrm{SE}=0.11) \mathrm{mg} / 10^{3}$ cells $/ \mathrm{mL}$ over the period of $7 \mathrm{wk}$. The cow effect accounted for 20.7 and $64.2 \%$ of the total variation before and after the breakpoint, respectively.

\section{DISCUSSION}

The main objective of this study was to estimate indirect and direct components of total tolerance to clinical mastitis. In this study, milk losses were mostly indirect and mediated by SCC. This was similar to previous findings in a study where TDM was within $70 \mathrm{~d}$ before diagnosis of clinical cases due to different pathogens (Detilleux et al., 2015). Highest total losses occurred in the first month of lactation, when SCC were highest: $0.5,0.8$, and $1.1 \mathrm{~kg} / \mathrm{d}$ in first, second, and third parity, respectively. By way of comparison, daily (total) losses in TDM were estimated at 0.7 to $3.7 \mathrm{~kg}$ in cows with clinical mastitis (Hagnestam-Nielsen et

Table 3. Regression coefficients (SE in parentheses) relating explanatory variables to test-day SCC (overdispersed Poisson model) and test-day milk yields (Gaussian linear model) ${ }^{1}$

\begin{tabular}{|c|c|c|c|}
\hline Explanatory variable & Category & $\begin{array}{c}\mathrm{SCC} \\
\left(\times 10^{3} \text { cells } / \mathrm{mL}\right)\end{array}$ & $\begin{array}{l}\text { Milk yield } \\
\quad(\mathrm{L} / \mathrm{d})\end{array}$ \\
\hline $\begin{array}{l}\text { Intercept } \\
\mathrm{SCC}\left(\times 10^{3} \text { cells } / \mathrm{mL}\right)\end{array}$ & & $\begin{array}{l}6.18(0.14) \\
\mathrm{NA}^{2}\end{array}$ & $\begin{array}{l}26.12(0.40) \\
-1.04(0.04) \times 10^{-3}\end{array}$ \\
\hline \multirow[t]{2}{*}{ Indicator variable } & Clinical signs & $0.90(0.07)$ & $-0.26(0.16)$ \\
\hline & No clinical signs & 0 (referent) & 0 (referent) \\
\hline \multirow[t]{3}{*}{ Parity } & 1 & $-0.86(0.04)$ & $-5.88(0.11)$ \\
\hline & 2 & $-0.53(0.04)$ & $-2.03(0.08)$ \\
\hline & 3 & 0 (referent) & 0 (referent) \\
\hline \multirow[t]{10}{*}{ Month in milk } & 1 & $0.19(0.07)$ & $8.49(0.13)$ \\
\hline & 2 & $-0.08(0.05)$ & $11.24(0.10)$ \\
\hline & 3 & $-0.10(0.05)$ & $11.28(0.10)$ \\
\hline & 4 & $-0.05(0.05)$ & $9.47(0.10)$ \\
\hline & 5 & $-0.07(0.05)$ & $7.74(0.10)$ \\
\hline & 6 & $0.03(0.05)$ & $6.25(0.10$ \\
\hline & 7 & $-0.07(0.05)$ & $4.73(0.10)$ \\
\hline & 8 & $-0.03(0.05)$ & $3.37(0.10)$ \\
\hline & 9 & $0.01(0.04)$ & $1.82(0.10)$ \\
\hline & 10 & 0 (referent) & 0 (referent) \\
\hline \multirow[t]{3}{*}{ Year of survey } & First & $0.09(0.07)$ & $-5.88(0.11)$ \\
\hline & Second & $0.29(0.06)$ & $-2.03(0.09)$ \\
\hline & Third & 0 (referent) & 0 (referent) \\
\hline \multirow[t]{4}{*}{ Month of sampling } & January-March & $0.19(0.06)$ & $1.27(0.11)$ \\
\hline & April-June & $0.12(0.06)$ & $2.25(0.11)$ \\
\hline & July-September & $0.18(0.06)$ & $0.61(0.11)$ \\
\hline & October-December & 0 (referent) & 0 (referent) \\
\hline \multirow[t]{3}{*}{ Interaction $\mathrm{SCC} \times$ parity } & 1 & NA & $0.28(0.08) \times 10^{-3}$ \\
\hline & 2 & NA & $0.00(0.00) \times 10^{-3}$ \\
\hline & 3 and over & NA & 0 (referent) \\
\hline
\end{tabular}

${ }^{1}$ The indicator variable is for the presence or not of clinical signs from $14 \mathrm{~d}$ before until $70 \mathrm{~d}$ after the day of diagnosis.

${ }^{2}$ Not applicable. 
al., 2009). In their review of the literature Seegers et al. (2003) reported a (total) loss of $375 \mathrm{~kg}$ for a clinical case, which is higher than overall loss observed in this study over the duration of changes in TDM (Figure 3). These differences can be explained by dissimilarities in the statistical methodologies, the animal populations, the involved pathogen strains, and the efficiency of treatments (Hortet and Seegers, 1998a).

Loss mediated by the increase in SCC is the product of 2 components (model [5]). The first component is a function of the expected difference in SCC in a cow with and without $\mathrm{CM}\left\{\hat{\mathrm{E}}\left[\mathrm{M}_{1}^{\mathrm{i}, \mathrm{t}}-\mathrm{M}_{0}^{\mathrm{i}, \mathrm{t}}\right]\right\}$. Biologically, this difference is the consequence of the migration of neu-
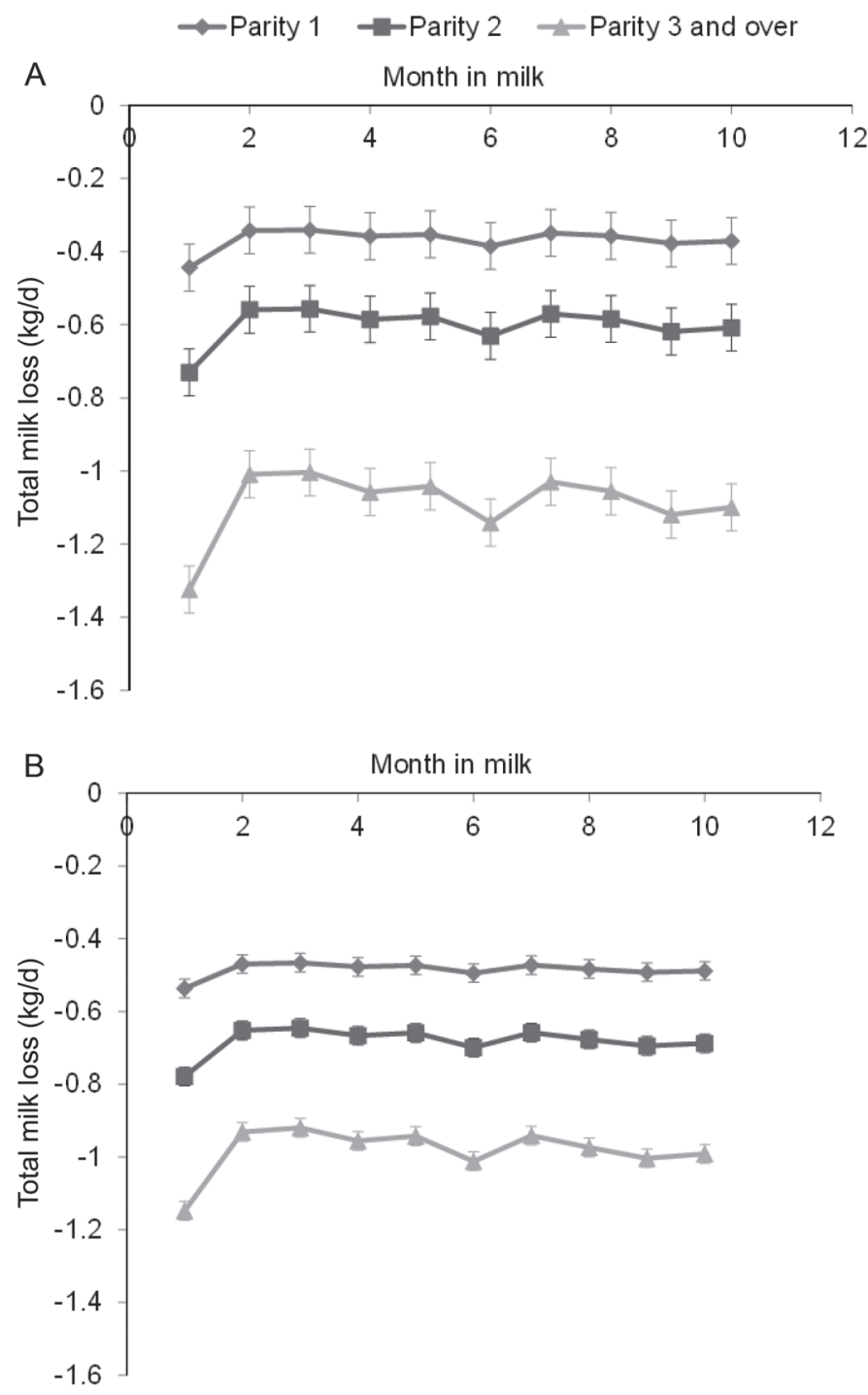

Figure 2. Estimated total loss in test-day milk yields due to clinical mastitis per month in milk and parity for samples taken at (A) the time of diagnosis, and (B) from $15 \mathrm{~d}$ before until $70 \mathrm{~d}$ after diagnosis. Error bars represent SE.

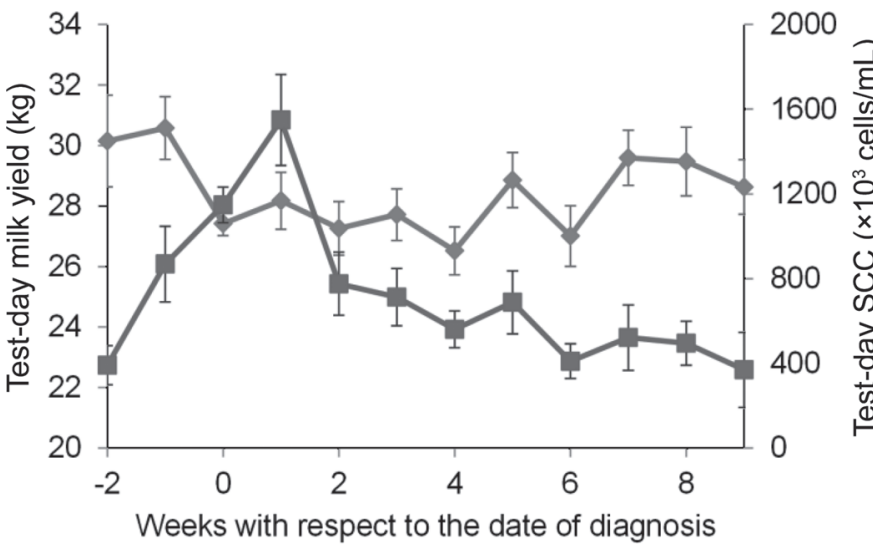

Figure 3. Observed weekly means of test-day milk yields ( $)$ and SCC (ם) sampled from $15 \mathrm{~d}$ before until $70 \mathrm{~d}$ after the day of diagnosis of mastitis. Error bars represent SE.

trophils (PMN) through the blood-milk barrier during mammary infection. Influx of PMN may cause local disruption of epithelial tight junctions that lead to leakage of plasma proteins into milk (e.g., Akers and Nickerson, 2011). This massive PMN diapedesis may also injure epithelial cells, resulting in necrosis (e.g., Harmon and Heald, 1982). The second component is the change in TDM per unit change in milk SCC. This component is also included in model [8], as used to analyze health trajectories before and after the breakpoint. One biological explanation for the loss per SCC is linked to the ability of PMN to release antibacterial peptides, enzymes (such as elastase, collagenase, ca-

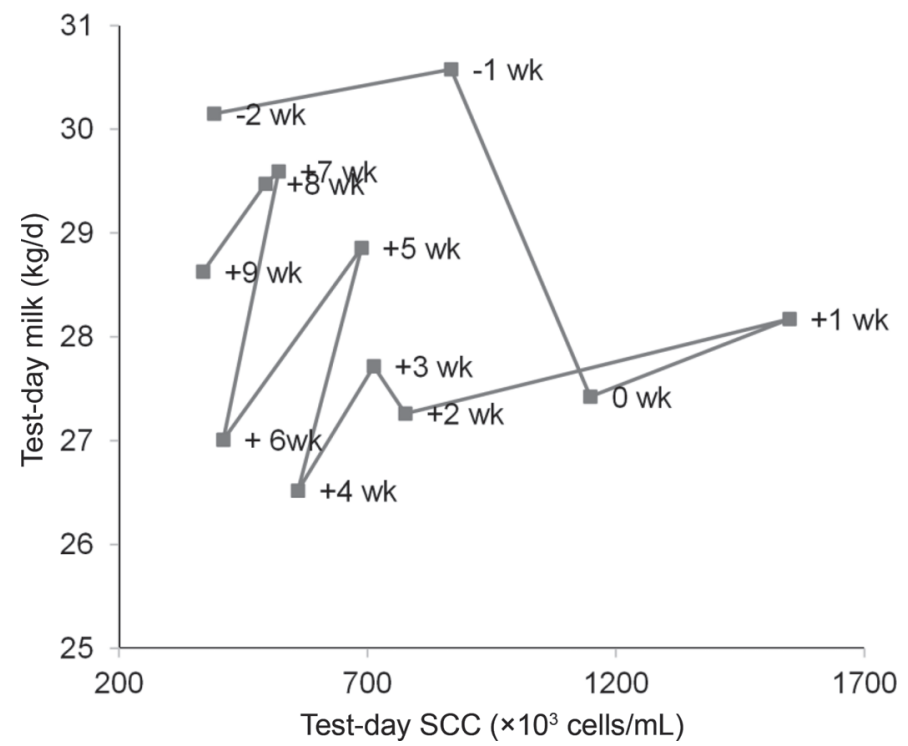

Figure 4. Trajectory relating observed means of test-day milk yield and SCC in different weeks before ( -2 and $-1 \mathrm{wk})$, at (0 wk), and after $(+1,+2, \ldots,+9 \mathrm{wk})$ the day of diagnosis of mastitis. 
thepsins, phosphatases, or lysozyme), and reactive oxygen species in the gland (e.g., Sharma et al., 2011).

Estimates of TDM loss per unit increase in SCC were $1 \mathrm{mg} / \mathrm{d}$ per $10^{3}$ cells $/ \mathrm{mL}$ for both indicators of mastitis (Tables 2 and 3). By way of comparison, Dürr et al. (2008) reported that daily milk loss per unit increase in the natural logarithm of test-day SCC varied from 0.5 to $2.1 \mathrm{mg}$ according to breed, parity, and stage of lactation (SCC in $10^{3}$ cells $/ \mathrm{mL}$ ). In Koldeweij et al. (1999), daily milk loss was 1.3 and $2 \mathrm{mg}$ for each unit increase in $\log _{10}(\mathrm{SCC})$ for first-lactation and older cows, respectively (SCC in $10^{3}$ cells $/ \mathrm{mL}$ ). In their review, Hortet and Seegers (1998b) reported a daily average loss in TDM of $0.4 \mathrm{~kg}$ in primiparous and $0.6 \mathrm{~kg}$ in multiparous animals for each 2 -fold increase of SCC above 50,000 cells $/ \mathrm{mL}$.

Indirect tolerance falls within the theory of the damage-response framework of microbial pathogenesis. In this theory, damage that occurs in infected hosts is the result of contributions from both the microbe and the host, and the outcome of this interaction can change as a function of time (Casadevall and Pirofski, 2003). In Figure 4, 2 phases described how changes in TDM were associated with changes in SCC. In the first phase, TDM decreases as SCC increases and in the second phase, the reverse happens; the magnitude of changes in TDM was not significantly different between phases. This trajectory is thus characteristic of a resilient system (Schneider, 2011). Deviations from the resilient path may explain why some cows are more or less (indirectly) tolerant (Torres et al., 2016). Here, cow effect accounted for 20.7 and $64.2 \%$ of the variation in TDM (corrected for effects in model [8]) before and after the breakpoint, respectively.

This suggests that deviations from the resilient path were highest after the breakpoint; that is, during the second phase of inflammation when tissue repair or regeneration occurs. One potential explanation for this finding is related to the switching of macrophages from the inflammatory M1 to the pro-generative M2 phenotypes (e.g., Ogle et al., 2016) during this period. This switch is highly dependent on the microenvironment around macrophages (e.g., Kapellos and Iqbal, 2016). By exploiting this epigenetic variation, we could improve bovine innate indirect tolerance to clinical mastitis. Indeed, many SNP associated with autoimmune or inflammatory diseases occur in regulatory regions that are subject to epigenetic regulation (Ivashkiv, 2013). For example, Satoh et al. (2010) have demonstrated that Jumonji domain-containing 3-interferon regulatory factor (Jmjd3-Irf4) axis regulates polarization of M2 macrophage and host responses. The repair process may also require the replacement of endothelial and epithelial dead cells with bone marrow-derived progenitor cells (Sharma and Jeong, 2013). Recently, Hu et al. (2016) produced immortalized bovine mammary epithelial cell lines capable of self-renewal and differentiation. Capuco et al. (2009) showed that infusion of xanthosine expands mammary stem and progenitor cell populations but results are still not conclusive.

Antioxidants may also decrease damage caused by PMN to mammary cells (Zhao and Lacasse, 2008). As an example, Chaiyotwittayakun et al. (2002) showed that intravenous injections of ascorbic acid increase milk production recovery, and Lauzon et al. (2006) reported that local mammary infusion of deferoxamine reduces PMN-induced damage caused by intramammary infusion of lipopolysaccharides on bovine mammary epithelial cells. Supplementation of mastitic cows with vitamins (e.g., A, C, E) and minerals (e.g., selenium, zinc, copper) also reduces duration of milk loss in some experiments (Spears and Weiss, 2008). Induction of PMN apoptosis would also limit the damage inflicted by PMN without interfering with their migration. Indeed, apoptosis can be modulated by drugs (Reed and Huang, 2004) or by selection. For example, Verbeke et al. (2014) observed an association of CXCR 1 polymorphisms with apoptosis, necrosis, and concentration of milk neutrophils. Note that not all cows recovered (Figure 3) within the time range considered in this study, which could further explain the cow effect observed in the second stage of the trajectory.

This study suffers from various limitations associated with its observational nature. First, data on clinical mastitis depended upon the willingness of farmers to report cases and their ability to correctly identify same clinical features of mastitis on each animal. The definition of (total) tolerance was different from that used after experimental exposition of hosts to equal pathogen burden level and based on (random) regression of host performance along increasing pathogen load (e.g., Råberg et al., 2007; Lough et al., 2015). The experimental design is obviously more appropriate than the one used in this study but requires costly laboratory investigations and does not completely reflect what happens in field studies. Also, it was not possible here to determine whether the indirect effect was strictly due to the migration of neutrophils and if the direct effect was only associated with bacterial virulence. Second, test-day records describe only monthly changes associated with clinical mastitis, whereas daily records collected with automatic sensor systems would undeniably be more valuable. Third, relationships between TDM and SCC did not involve reciprocal links, even though some authors have observed a very small, but statistically significant, positive effect of milk on SCC in cows 
with and without clinical mastitis (e.g., Jamrozik et al., 2010). Also, the models developed here did not fit lagged relationships, even though SCC in previous days could theoretically influence TDM in later days. However, this was not observed in the study of Jamrozik et al. (2010). It was also unfeasible to determine the bacteriological etiology of clinical cases even though important differences exist between infection caused by different bacterial species and strains. This information would have shed more light on biological mechanisms behind milk loss components.

\section{ACKNOWLEDGMENTS}

The author thanks the Association Wallonne de l'Elevage, the Observatoire de la Santé Mammaire en Wallonie (OSAM), researchers from the Theriogenology group from the University of Liege and breeders for providing records on test-day milk and somatic cell counts and on clinical mastitis.

\section{REFERENCES}

Akers, R. M., and S. C. Nickerson. 2011. Mastitis and its impact on structure and function in the ruminant mammary gland. J. Mammary Gland Biol. Neoplasia 16:275-289.

Capuco, A. V., C. M. Evock-Clover, A. Minuti, and D. L. Wood. 2009 In vivo expansion of the mammary stem/progenitor cell population by xanthosine infusion. Exp. Biol. Med. (Maywood) 234:475-482.

Carnegie, N. B., M. Harada, and J. L. Hill. 2016. Assessing sensitivity to unmeasured confounding using a simulated potential confounder. J. Res. Educ. Eff. 9:395-420.

Casadevall, A., and L.-A. Pirofski. 2003. The damage-response framework of microbial pathogenesis. Nat. Rev. Microbiol. 1:17-24.

Chaiyotwittayakun, A., R. J. Erskine, P. C. Barlett, T. H. Herdt, P. M. Seras, and R. J. Harmon. 2002. The effect of ascorbic acid and L-histidine therapy on acute mammary inflammation in dairy cattle. J. Dairy Sci. 85:60-67.

Detilleux, J., J. P. Kastemi, and H. W. Barkema. 2015. Mediation analysis to estimate direct and indirect milk losses due to clinical mastitis in dairy cattle. Prev. Vet. Med. 118:449-456.

Dürr, J. W., R. I. Cue, H. G. Monardes, J. Moro-Mendez, and K. M. Wade. 2008. Milk losses associated with somatic cell counts per breed, parity and stage of lactation in Canadian dairy cattle. Livest. Sci. 117:225-232.

Gröhn, Y. T., D. J. Wilson, R. N. Gonzalez, J. A. Hertl, H. Schulte, G. Bennett, and Y. H. Schukken. 2004. Effect of pathogen-specific clinical mastitis on milk yield in dairy cows. J. Dairy Sci. 87:3358-3374.

Hagnestam-Nielsen, C., U. Emanuelson, B. Berglund, and E. Strandberg. 2009. Relationship between somatic cell count and milk yield in different stages of lactation. J. Dairy Sci. 92:3124-3133.

Harmon, R. J., and C. W. Heald. 1982. Migration of polymorphonuclear leukocytes into the bovine mammary gland during experimentally induced Staphylococcus aureus mastitis. Am. J. Vet. Res. 43:992-998.

Hortet, P., and H. Seegers. 1998a. Loss in milk yield and related composition changes resulting from clinical mastitis in dairy cows. Prev. Vet. Med. 37:1-20.

Hortet, P., and H. Seegers. 1998b. Calculated milk production losses associated with elevated somatic cell counts in dairy cows: Review and critical discussion. Vet. Res. 29:497-510.
Hu, H., N. Zheng, H. Gao, W. Dai, Y. Zhang, S. Li, and J. Wang. 2016. Immortalized bovine mammary epithelial cells express stem cell markers and differentiate in vitro. Cell Biol. Int. 40:861-872.

Ivashkiv, L. B. 2013. Epigenetic regulation of macrophage polarization and function. Trends Immunol. 34:216-223.

Jamrozik, J., J. Bohmanova, and L. R. Schaeffer. 2010. Relationships between milk yield and somatic cell score in Canadian Holsteins from simultaneous and recursive random regression models. J. Dairy Sci. 93:1216-1233.

Kapellos, T. S., and A. J. Iqbal. 2016. Epigenetic control of macrophage polarisation and soluble mediator gene expression during inflammation. Mediators Inflamm. https://doi.org/10.1155/2016/ 6591703.

Koldeweij, E., U. Emanuelson, and L. Janson. 1999. Relation of milk production loss to milk somatic cell count. Acta Vet. Scand. 40:4756.

Lauzon, K., X. Zhao, and P. Lacasse. 2006. Deferoxamine reduces tissue during endotoxin-induced mastitis in dairy cows. J. Dairy Sci. 89:3846-3857.

Lough, G., I. Kyriazakis, S. Bergmann, A. Lengeling, and A. B. Doeschl-Wilson. 2015. Health trajectories reveal the dynamic contributions of host genetic resistance and tolerance to infection outcome. Proc. Biol. Sci. 282:20152151.

MacKinnon, D. P., C. M. Lockwood, J. M. Hoffman, S. G. West, and V. Sheets. 2002. A comparison of methods to test mediation and other intervening variable effects. Psychol. Methods 7:83-104.

Ogle, M. E., C. E. Segar, S. Sridhar, and E. A. Botchwey. 2016. Monocytes and macrophages in tissue repair: Implications for immunoregenerative biomaterial design. Exp. Biol. Med. (Maywood) 241:1084-1097.

Råberg, L., D. Sim, and A. F. Read. 2007. Disentangling genetic variation for resistance and tolerance to infectious diseases in animals. Science 318:812-814.

Reding, E., L. Theron, J. Detilleux, C. Bertozzi, and C. Hanzen. 2011. LAECEA: Un outil fédérateur d'aide à la décision pour le suivi de la santé mammaire dans les élevages bovins laitiers wallons. Recherches Rencontres Ruminants. Accessed Jun. 15, 2017. http:// www.journees3r.fr/spip.php?article3311.

Reed, J. C., and Z. Huang. 2004. Apoptosis pathways and drug targets. Nat. Rev. Drug Discov. Mol. Cell Biol. Accessed Jun. 15, 2017. http://www.nature.com/reviews/poster/apoptosis/index .html.

Richiardi, L., R. Bellocco, and D. Zugna. 2013. Mediation analysis in epidemiology: Methods, interpretation and bias. Int. J. Epidemiol. 42:1511-1519.

Satoh, T., O. Takeuchi, A. Vandenbon, K. Yasuda, Y. Tanaka, Y. Kumagai, T. Miyake, K. Matsushita, T. Okazaki, T. Saitoh, K. Honma, T. Matsuyama, K. Yui, T. Tsujimura, D. M. Standley, K. Nakanishi, K. Nakai, and S. Akira. 2010. The Jmjd3-Irf4 axi regulates M2 macrophage polarization and host responses against helminth infection. Nat. Immunol. 11:936-944.

Schneider, D. S. 2011. Tracing personalized health curves during infections. PLoS Biol. 9:e1001158. https://doi.org/10.1371/journal .pbio. 1001158 .

Seegers, H., C. Fourichon, and F. Beaudeau. 2003. Production effects related to mastitis and mastitis economics in dairy cattle herds. Vet. Res. 34:475-491.

Sharma, N., and D. K. Jeong. 2013. Stem cell research: A novel boulevard towards improved bovine mastitis management. Int. J. Biol. Sci. 9:818-829.

Sharma, N., N. K. Singh, and M. S. Bhadwal. 2011. Relationship of somatic cell count and mastitis: An overview. Asian-australas. J. Anim. Sci. 24:429-438.

Spears, J. W., and W. P. Weiss. 2008. Role of antioxidants and trace elements in health and immunity of transition dairy cows. Vet. J. 176:70-76

Torres, B. Y., J. H. Oliveira, A. T. Tate, P. Rath, K. Cummock, and D. Schneider. 2016. Tracking resilience to infections by mapping disease space. PLoS Biol. 14:1002436. 
Vanderweele, T. J., and S. Vansteelandt. 2009. Conceptual issues concerning mediation, interventions and composition. Stat. Interface $2: 457-468$

Verbeke, J., S. Piepers, L. Peelman, M. Van Poucke, and S. De Vliegher. 2014. Association of CXCR1 polymorphisms with apoptosis, necrosis and concentration of milk neutrophils in early lactating dairy heifers. Res. Vet. Sci. 97:55-59.

Zhao, X., and P. Lacasse. 2008. Mammary tissue damage during bovine mastitis: Causes and control. J. Anim. Sci. 86:57-65.

\section{APPENDIX}

Given the models for TDM and SCC, total, direct, and indirect losses can be expressed as follows. Total loss is given by Model [3]:

$$
\begin{gathered}
\mathrm{E}\left[\mathrm{Y}_{1, \mathrm{M}(1)}^{\mathrm{i}, \mathrm{t}}-\mathrm{Y}_{0, \mathrm{M}(0)}^{\mathrm{i}, \mathrm{t}(\mathrm{l})}\right] \\
=\beta_{1}+\left(\beta_{2}+\beta_{4}\right)\left\{\mathrm{E}\left[\mathrm{M}_{(1)}^{\mathrm{i}, \mathrm{t}}\right]-\beta_{2} \mathrm{E}\left[\mathrm{M}_{(0)}^{\mathrm{i}, \mathrm{t}}\right]\right\}+\mathrm{C}_{(1)}^{\mathrm{i}, \mathrm{t}}\left\{\beta_{3}\right. \\
\left.+\beta_{6}+\left(\beta_{5}+\beta_{7}\right) \mathrm{E}\left[\mathrm{M}_{(1)}^{\mathrm{i}, \mathrm{t}}\right]\right\}-\mathrm{C}_{(0)}^{\mathrm{i}, \mathrm{t} t}\left\{\beta_{3}+\beta_{5} \mathrm{E}\left[\mathrm{M}_{(0)}^{\mathrm{i}, \mathrm{t}}\right]\right\} \\
=\beta_{1}+\left(\beta_{2}+\beta_{4}\right)\left\{\exp \left[\mu+\delta_{1}+\left(\delta_{3}+\delta_{6}\right) \mathrm{C}_{(1)}^{\mathrm{i}, \mathrm{t} t}\right]\right. \\
\left.-\beta_{2} \exp \left(\mu+\delta_{3} \mathrm{C}_{(0)}^{\mathrm{i}, \mathrm{t}}\right)\right\}+\mathrm{C}_{(1)}^{\mathrm{i}, \mathrm{t}}\left\{\beta_{3}+\beta_{6}+\left(\beta_{5}+\beta_{7}\right)\right. \\
\left.\exp \left[\mu+\delta_{1}+\left(\delta_{3}+\delta_{6}\right) \mathrm{C}_{(1)}^{\mathrm{i}, \mathrm{t}}\right]\right\}-\mathrm{C}_{(0)}^{\mathrm{i}, \mathrm{t}} \\
\left\{\beta_{3}+\beta_{5} \exp \left(\mu+\delta_{3} \mathrm{C}_{(0)}^{\mathrm{i}, \mathrm{t}}\right)\right\} .
\end{gathered}
$$

Direct loss is given by Model [4]:

$$
\begin{gathered}
\frac{1}{2} \mathrm{E}\left\{\left[\mathrm{Y}_{1, \mathrm{M}(1)}^{\mathrm{i}, \mathrm{t}}-\mathrm{Y}_{0, \mathrm{M}(1)}^{\mathrm{i}, \mathrm{t}}\right]+\left[\mathrm{Y}_{1, \mathrm{M}(0)}^{\mathrm{i}, \mathrm{t}}-\mathrm{Y}_{0, \mathrm{M}(0)}^{\mathrm{i}, \mathrm{t}}\right]\right\} \\
=\beta_{1}+1 / 2 \beta_{4}\left\{\mathrm{E}\left[\mathrm{M}_{(1)}^{\mathrm{i}, \mathrm{t}}\right]+\mathrm{E}\left[\mathrm{M}_{(0)}^{\mathrm{i}, \mathrm{t}}\right]\right\}+1 / 2 \beta_{6}\left\{\mathrm{C}_{(1)}^{\mathrm{i}, \mathrm{t}}\right. \\
\left.+\mathrm{C}_{(0)}^{\mathrm{i}, \mathrm{t}}\right\}+1 / 2 \beta_{7}\left\{\mathrm{C}_{(1)}^{\mathrm{i}, \mathrm{t}} \mathrm{E}\left[\mathrm{M}_{(1)}^{\mathrm{i}, \mathrm{t}}\right]+\mathrm{C}_{(0)}^{\mathrm{i}, \mathrm{t}} \mathrm{E}\left[\mathrm{M}_{(0)}^{\mathrm{i}, \mathrm{t}}\right]\right\} \\
=\beta_{1}+1 / 2 \beta_{4}\left\{\exp \left[\mu+\delta_{1}+\left(\delta_{3}+\delta_{6}\right) \mathrm{C}_{(1)}^{\mathrm{i}, \mathrm{t}}\right]\right. \\
\left.+\exp \left(\mu+\delta_{3} \mathrm{C}_{(0)}^{\mathrm{i}, \mathrm{t}}\right)\right\}+\beta_{6}\left\{\mathrm{C}_{(1)}^{\mathrm{i}, \mathrm{t}}+\mathrm{C}_{(0)}^{\mathrm{i}, \mathrm{t}}\right\} \\
+1 / 2 \beta_{7}\left\{\mathrm{C}_{(1)}^{\mathrm{i}, \mathrm{t}} \exp \left[\mu+\delta_{1}+\left(\delta_{3}+\delta_{6}\right) \mathrm{C}_{(1)}^{\mathrm{i}, \mathrm{t} t}\right]\right. \\
\left.+\mathrm{C}_{(0)}^{\mathrm{i}, \mathrm{t}} \exp \left(\mu+\delta_{3} \mathrm{C}_{(0)}^{\mathrm{i}, \mathrm{t}}\right)\right\} .
\end{gathered}
$$

Indirect loss is given by Model [5]:

$$
\begin{gathered}
\frac{1}{2} \mathrm{E}\left\{\left[\mathrm{Y}_{0, \mathrm{i}(1)}^{\mathrm{i}, \mathrm{t}(1)}-\mathrm{Y}_{0, \mathrm{M}(0)}^{\mathrm{i}, \mathrm{t}}\right]+\left[\mathrm{Y}_{1, \mathrm{i}(1)}^{\mathrm{i}, \mathrm{t}(1)}-\mathrm{Y}_{1, \mathrm{M}(0)}^{\mathrm{i}, \mathrm{t}(0)}\right]\right\} \\
=\left(\beta_{2}+1 / 2 \beta_{4}\right)\left\{\mathrm{E}\left[\mathrm{M}_{(1)}^{\mathrm{i}, \mathrm{t}}-\mathrm{M}_{(0)}^{\mathrm{i}, \mathrm{t}}\right]\right\}+\left(\beta_{3}+1 / 2 \beta_{6}\right) \\
\left\{\mathrm{C}_{(1)}^{\mathrm{i}, \mathrm{t}}-\mathrm{C}_{(0)}^{\mathrm{i}, \mathrm{t}}\right\}+\left(\beta_{5}+1 / 2 \beta_{7}\right)\left\{\mathrm{C}_{(1)}^{\mathrm{i}, \mathrm{t}} \mathrm{E}\left[\mathrm{M}_{(1)}^{\mathrm{i}, \mathrm{t}}\right]\right. \\
\left.-\mathrm{C}_{(0)}^{\mathrm{i}, \mathrm{t}} \mathrm{E}\left[\mathrm{M}_{(0)}^{\mathrm{i}, \mathrm{t}}\right]\right\} \\
=\left(\beta_{2}+1 / 2 \beta_{4}\right)\left\{\exp \left[\mu+\delta_{1}+\left(\delta_{3}+\delta_{6}\right) \mathrm{C}_{(1)}^{\mathrm{i}, \mathrm{t}}\right]\right. \\
\left.-\exp \left(\mu+\delta_{3} \mathrm{C}_{(0)}^{\mathrm{i}, \mathrm{t}}\right)\right\}+\left(\beta_{3}+1 / 2 \beta_{6}\right)\left\{\mathrm{C}_{(1)}^{\mathrm{i}, \mathrm{t}}-\mathrm{C}_{(0)}^{\mathrm{i}, \mathrm{t}}\right\} \\
+\left(\beta_{5}+1 / 2 \beta_{7}\right)\left\{\mathrm{C}_{(1)}^{\mathrm{i}, \mathrm{t}} \exp \left[\mu+\delta_{1}+\left(\delta_{3}+\delta_{6}\right) \mathrm{C}_{(1)}^{\mathrm{i}, \mathrm{t} t}\right]\right. \\
\left.-\mathrm{C}_{(0)}^{\mathrm{i}, \mathrm{t}} \exp \left(\mu+\delta_{3} \mathrm{C}_{(0)}^{\mathrm{i}, \mathrm{t}}\right)\right\} .
\end{gathered}
$$

Standard errors for these estimates were based on first- and second-order Taylor series approximation of the product of regression coefficients; that is, $\Pi_{i}\left\{\operatorname{var}\left(b_{i}\right)+E\left(b_{i}\right)^{2}\right\}-\Pi_{i}\left\{E\left(b_{i}\right)^{2}\right\}$, where $b_{i}$ are the estimated regression coefficients in the above formula for the total, direct, and indirect losses. A z-test was used to test null hypotheses of no loss, as suggested by MacKinnon et al. (2002). 